\title{
Learning Languages without Grammar
}

\author{
Nihat Aksu1 \\ Ünal Gönül2 \\ ${ }^{1}$ European University of Tirana, Tirana, Albania \\ Email: nihataksu@yahoo.com \\ ${ }^{2}$ Hëna e Plotë Beder University, Tirana, Albania
}

\section{Doi:10.5901/jesr.2014.v4n2p39}

\begin{abstract}
This article presents how natural approach is effective in teaching or learning language using this Natural Approach learners will be able to elicit the language like small children are learning their mother tongue in their family. Many language teachers of English, Turkish and Arabic insist on the structure of the language, they claimed that it should be firstly taught the grammar then the learner will be able to learn and use it. This paper examines Stephen Krashen, and Tracy David Terrell's The Natural Approach. Whereas well-given examples of Communicative Approach that, was developed by Robert Langs MD, in the early 1970 's. The results show that learners should get input in the current language. By using and practicing the input, language learners will get improvement. The work presented here was profound implications for future studies of language learning and may help solve the problem of practicing foreign language.
\end{abstract}

Keywords: natural approach, comprehension-based language, communicative approach

\section{Learning Languages without Grammar}

This article discusses about how languages can be taught and learned. Lemonick (1994) wrote in Time magazine, an article with a title "How man began". The bold argument in the article was: "No single, essential difference separates human beings from other animals"(Lemonick, 1994). Some linguistic scientists claim that communication is done via speech. It is the most important distinguishing between humans and animals. Lieberman (1998) sustained: "Speech is so essential to our concept of intelligence that its possession is virtually equated with being human. Animals who talk are human, because what sets us apart from other animals is the 'gift' of speech" in his book, Eve Spoke (Lieberman, 1998).

If we are looking through history, it can be understood that the human being firstly got in touch with each other by speeches many thousand years ago. The written form of languages just appeared in the years $3500 \mathrm{BC}$. Whereas the structure of languages can be seen in the last some hundred years. Our rich and sophisticated communication sets us apart from other creatures on our planet.

\section{Natural Approach}

It is an approach in which real communication is the basis of class activities and within a short time a learner can communicate with native speaker of that target language. It does not require the ability to communicate or grammartranslation, audio-lingual and different eclectic cognitive-based methods. It produces skills that suits exactly what is taught (Khattak \& Asrar, 2007).

There are three principles in Natural Approach to language acquisition: (1) the classroom activities must cultivate acquisition (activities which promote learning might be assigned as homework. (2) No correction of speech errors directly. (3) The learners can respond in either the target language, or their native language or a mixture of the two. The most important principle is that acquisition activities that are provided in the class because these activities allow the progress of communicative abilities in addition to fostering the kind of knowledge that result from conscious cognitive learning exercises (Khattak \& Asrar, 2007).

According to Stephen D. Krashen (1982), independent ways of developing competence in the second languages are: acquisition and learning."Acquisition is a subconscious process that is similar to the way that children develop ability to speak in a first language. Learning is the conscious knowledge of grammar rules and their application to verbal 
production in a second language" (Stephen D. Krashen, 1982).

The basic principles of the Natural Approach (Terrell, 1977) is listed as following: 1) Beginning language instruction should focus on the attainment of communicative competence (immediately) rather than on grammatical perfection.2) Instruction need to be designed modifying and improving the students developing grammar rather than at building language experiences based upon grammar-one rule at a time.3) Teachers should provide students with opportunities to acquire language naturally rather than in a forced classroom environment.4) Affective factors should precede cognitive factors during language learning experiences.5) Acquisition of vocabulary is the key to comprehension and oral production (Terrell, 1977).

As stated by Terrell (1977), "a student with a large enough vocabulary can comprehend and speak a great deal of L2 (second Language) even if his/her knowledge of the grammatical structure is nonexistent".

Krashen's (1982) monitor theory claims that oral proficiency is not cognate to high scores on standard grammar tests, a fact conventionally looked out over by language educators who claim to have communicative competence as a target but perpetuate to evaluate progress only in the cognition of grammar rules (Stephen D. Krashen, 1982). Nowadays all the national or international English Exams lead the students the rules of grammar to get a certificate, to pass to university or to be applied to a position.

Some state that learned rules can be acquired through practice. This credence seems to refer to the three-part technique of cognitive approaches: explication, practice and application. The follower of cognitive approaches, Chastain (1976) believe that comprehension of the rule must precede its use. The cognition of grammatical principle can precede its acquisition. Whether, it promotes acquisition probably depends on the cognition style of the acquirer. Research shows that acquisition takes place under certain conditions. In the communication situation: (a) the focus is on the message; (b) the acquirer must understand the message; and (c) the acquirer must be in a low-solicitousness situation (Khattak \& Asrar, 2007).

Hatch (1979) gives the following tips for the speech to be understood by the listeners: slower rate (clear articulation, diminished contraction, long pauses, extra volume, exaggerated intonation);understandable vocabulary (high-frequency vocabulary, less slang, few idioms, high use of names of referents instead of performs); marked definitions (explaining a term that the speaker doubts the learner will know, repetitions, gestures, pictures); simplification of syntax vis-à-vis the meaning (simple propositions, focus on topics, repetition and restatement, less proverbs' modification, helping the learner complete utterances); discourse techniques (giving a possible answer within the question, yes-no question, tag question) (Hatch, 1979; Khattak \& Asrar, 2007).

Children learn their native language eliciting before they start to speak (Fraser, Bellugi, \& Brown, 1966). In reality, competence of all speakers in comprehension gives birth to competence in production. Winitz and Reeds (1973) estimate that in the first language acquisition 'comprehension' comes before a sentence generating approximately a year. "This sequence of development-comprehension first, production second-is a functional property of the human brain which should not be violated in language instruction." (Winitz \& Reeds, 1973)

How to make intelligent conjectures profit in the early stages of acquiring language. The major components are: (1) a context; (2) gestures and body language cues; (3) message to be comprehended; (4) a knowledge of the meaning of the key lexical items in the utterance. Grammatical signals are not usually crucial to the comprehension task of beginning students (Khattak \& Asrar, 2007).

Snow (1979) notes that "children figure out rules underlying syntactic by using the cues provided by the meaning of the adult's utterance". Following Snow (1979) describes the process for children exactly as the natural approach suggests for adults: "knowledge of the meaning of important lexical items plus knowledge of what is likely to be said about those entities or actions given the situation enable the child to guess correctly what the utterance means. This implies of course that the child must be a good guesser, but also that the adult must say the kind of things the child expects to hear" (Snow, 1979).

In his writing Fries (1945) takes the opposite view: "in learning a new language, then, the chief problem is not at first that of learning vocabulary items. It is, first, the mastery of the features of arrangement that constitute the structure of the language."(Fries, 1945)

Natural Approach is based on Asher's (2009)Total Physical response in which the teachers ask students to perform certain action, such as close your eyes. Another Technique, which is useful in the first few days of class, makes use of the students' names and descriptions. The following is an example of 'teacher talk', that is, comprehensible input: 
What is your name? (Ammy.)

Everyone look at Ammy. Ammy has long, black hair. What is the name of the student with long, black hair? (Class responds with a name only.) What is your name (selecting another student)? (Henry.) Look at Henry. Does Henry have long hair? (Use gestures to contrast long and short.) (Class responds, no.) Is his hair black? (No) Is it brown (use context and gestures)? (Yes.) Henry is the student with short, brown hair. What is the name of the student with long, Black hair? (Ammy) And the student with short, brown hair? (Henry) This activity can be continued using physical characteristics (positive attributes only) and clothing colors and some simple descriptions (Khattak \& Asrar, 2007).

\section{Communicative Language Teaching}

What is communicative language teaching? (CLT)

When we are asking the language teachers this question they would possible say that this is methodology of choice in teaching. However, when we give present and give the detailed explanation of what "communicative" means, its explanation verifies wide. Does CLT mean teaching conversation, the absence of grammar in a classroom or an insistence on open-ended discussion activities, which requires the main points of the course? What do you understand by communicative language teaching or learning?

The following statements below characterize communicative language teaching: (a) effective language learning way is through using it, but not learning the structure of it (b) grammar is unnecessary in language teaching (c) impact of communication is essential in language learning (d) errors in speaking a language are not important (e) CLT is only interested in teaching and speaking (f) classroom activities ought to be meaningful and everyday communication (g) dialogs are not useful (h) accuracy and fluency are the target in CLT (i) CLT is usually described as a method of teaching (Jack C. Richards, 2006). Communicative Language Teaching can be considered as a set of principles about the target of language teaching how learners learn a language, the ways of classroom activities that best fits learning depends on the teacher and the learner's ability and capability.CLT pioneers have become interested in integrating form-focused instruction with communicative activities (Wong \& Barrea-Marlys, 2012).

One of the essential goals of CLT is to improve fluency in language use. "Fluency is natural language use occurring when a speaker engages in meaningful interaction and maintains comprehensible and ongoing communication according limitations in his or her communicative competence" (Wong \& Barrea-Marlys, 2012). Since the language classrooms are places where learners are intended to be prepared for survival in the real world. There should be a correlation between classroom activities and real life. The Pedagogs argued that class activities should be as far as possible mirror the real world and use real world or authentic sources as the basic for classroom learning. These studies provide evidence that each competence plays a significant role in the acquisition of communicative competence. However, teachers seem to deemphasize grammar accuracy in their CLT classrooms (Wong \& Barrea-Marlys, 2012). Whereas Clark and Silberstein (2005) argued:

Classroom activities should parallel the 'real world' as closely as possible. Since language is a tool of communication, methods and materials should concentrate on the message and not the medium. The purposes of reading should be the same in class as they are in real life. Others criticized that it is not important if classroom materials themselves are divided from authentic texts and other forms of input, as long as learning processes they facilitated were authentic (Jack C. Richards, 2006).

\section{Conclusion}

While people are speaking their native language or foreign language, none of them are firstly making up sentences in their mind then produce it. Normally, the output of language, it does not matter if it is native or foreign language is coming out according to elicit or input of target language. By listening, watching and reading we do the input of a language. Especially while you are reading a book logically you may think that you did not get anything at all, but while you are speaking the words, phrases and sentences are coming out unconsciously from your lips and mouth. Natural Approach uses different techniques and activities in source to provide comprehensive input. In teaching language, communicative activities are applied by Natural Approach, considering in different activities such as games, role- play, dialogs, group work and discussions.

As it is mentioned before there are three genetic phases identified with the approach: (1) preproductiondeveloping listening skills (2) early Production- learners struggle with the language and make many errors which are corrected based on content and not structure (3) extending Production- promoting fluency through a variety of more challenging activities"(Stephen D Krashen \& Terrell, 1983). 
To have language acquisition the language processing should be given to the learner the correct comprehensive input from the teacher. We hope that this writing will guide the language teachers to teach their target language to their learners in a natural way without too much of effort.

\section{References}

Asher, J. J. (2009). Learning Another Language Through Actions (New 7th edition ed.): Sky Oak Productions.

Chastain, K. (1976). Developing second-language skills: Theory to practice: Houghton Mifflin.

Fraser, C., Bellugi, U., \& Brown, R. (1966). Control of Grammar in Invitation, Comprehension, and Production. Verbal Learning Verbal Behaviour, 2, 121-135.

Fries, C. (1945). Teaching \& learning English as a foreign language: University of Michigan Press.

Hatch, E. (1979). Simplified input and second language acquisition. Paper presented at the Annual Meeting of the Linguistic Society of America, Los Angeles.

Khattak, I., \& Asrar, M. (2007). Stages of Language Acquisition in the Natural Approach to Language Teaching. Sarhad J. Agric, 23(1), 251-255.

Krashen, S. D. (1982). Principles and Practice in Second Language Acquisition: Alemany Pr.

Krashen, S. D., \& Terrell, T. D. (1983). The natural approach: Pergamon Oxford.

Lemonick, M. D. (1994). How man began. [Article]. cover story, 143, 80-87.

Lieberman, P. (1998). Eve Spoke: Human Language and Human Evolution: W. W. Norton \& Company.

Richards, J. C. (2005). Communicative language teaching today: SEAMEO Regional Language Centre.

Richards, J. C. (2006). Communicative Language Teaching Today. United States of America: Cambridge University Press.

Snow, C. (1979). Conversation with children Language acquisition: studies in First Language Dev., 363-376.

Terrell, T. D. (1977). A Natural Approach to Second Language Acquisition and Learning. Modern Language Journal, 61(7), 325-337.

Winitz, H., \& Reeds, J. (1973). Rapid acquisition of a foreign language (German) by the avoidance of speaking. International Review of Applied Linguistics, 11(4), 295-317.

Wong, C. C. Y., \& Barrea-Marlys, M. (2012). The Role of Grammar in Communicative Language Teaching:An Exploration of Second Language Teachers' Perceptions and Classroom Practices. Electronic Journal of Foreign Language Teaching, 9(1), 61-75. 